Francesco Massa

\title{
Reading and Rewriting Euripides in Clement of Alexandria
}

\begin{abstract}
The paper analyses the Euripidean quotations in Clement of Alexandria, in order to explore the different rhetorical strategies used by the Christian author. Quantitative analyses revealed that Euripides' texts are frequently quoted (117 passages according to Stählin edition): only Plato and Homer are more popular in Clement. In the late second-century Alexandria, Euripidean tragedies are not only a key reference in the Graeco-roman paideia; in Clement's works, Euripides also plays a cultural role in the dialogue between "Pagans" and "Christians". To take just one example, in the last book of the Exhortation to the Greeks, Clement evokes some images taken from Euripides' Bacchae to call for conversion to Christianity: Pentheus and Tiresias are encouraged to return to Christian moderation and to reject Dionysian wine and madness on the basis of a re-reading and on a re-writing of the Bacchae.
\end{abstract}

According to the Christian tradition, Clement was born in Athens or in Alexandria around 150. ${ }^{1}$ In the Preparation for the Gospel, Eusebius of Caesarea reports that, prior to his conversion, Clement was well-versed in the Greek religion, including perhaps the mystery cults. ${ }^{2}$ Clement himself mentions his several journeys in the Eastern regions of the Empire - Greece, Asia Minor, Palestine and Egypt - where he had the chance to further refine his training. ${ }^{3}$ Later on, in Alexandria, Clement joined the circle of Pantaenus, to whom he succeeded. ${ }^{4}$ According to Eusebius of Caesarea, "having succeeded Pantaenus, Clement had charge at that time of the catechetical instruction

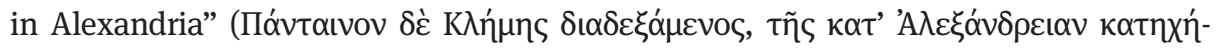

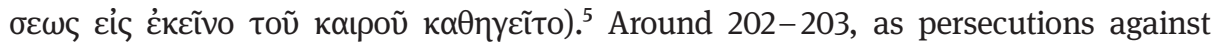

1 On Clement's biography, see Osborn 2005, 1-27.

2 Eus. Praep. ev. 2,2,64: “[...] a man who had gone through experience of all sorts, but had quickly emerged from the delusion as one who had been rescued from evil by the word of salvation and

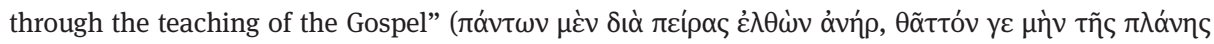

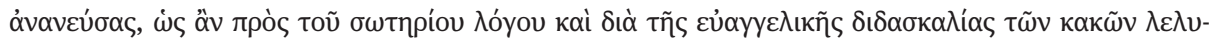
$\tau \rho \omega \mu \varepsilon \dot{v o \zeta)}$. On this point, see Massa 2016 and Massa, forthcoming.

3 Clem. Al. Strom. 1,1,2.

4 Eus. Hist. eccl. 5,10,4: "Pantaenus finally became the head of the school at Alexandria, and ex-

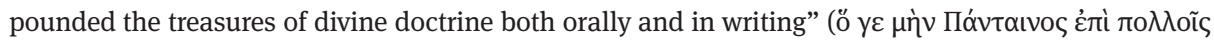

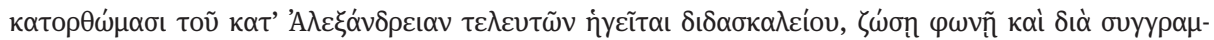

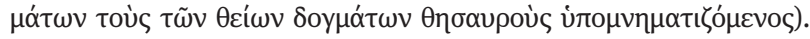

5 Eus. Hist. eccl. 6,6,1.

https://doi.org/10.1515/9783110677072-018 
the Christians raged in Alexandria, ${ }^{6}$ Clement had to leave for Cappadocia. There, he found protection from Alexander, bishop of Caesarea. ${ }^{7}$

The Christian tradition portrays Clement as a second-century intellectual with a vast travelling experience and acquaintance with different cultural traditions of the Roman Empire. His representation recalls in some way that of a member of the Second Sophistic. ${ }^{8}$

From the Hellenistic period onwards, Alexandria had been the cradle of the rich knowledge and traditions of the ancient Mediterranean. ${ }^{9}$ It had been host to refined intellectuals and seen the cohabitation of the Greek and Jewish culture, as well as of the Christian and "Gnostic" theologies. Alexandria is hence a privileged terrain to study the religious rivalries and the socio-political issues between Pagans and Christians. ${ }^{10}$ Not coincidentally, between the $2^{\text {nd }}$ and the $5^{\text {th }} \mathrm{c}$. BC, the Alexandrian milieu included such Christian authors as Clement, Origen (and three generations before, probably also his enemy Celsus), Athanasius and Cyril. The "School of Alexandria" played a fundamental role in the construction of ancient Christian theologies. ${ }^{11}$ Clement was, therefore, first of all, an intellectual with a strong, traditional Greek background. His sophisticated paideia was the result of a high-level rhetorical and philosophical training, in which Platonist and Aristotelian speculations combined with the author's specific knowledge and the fundamental texts of Greek culture. ${ }^{12}$

Clement's works contain more than a hundred citations of Euripides' tragedies. ${ }^{13}$ This makes Euripides fifth among the most-cited authors - after Paul, Plato, Philon of Alexandria, and Homer - and third amongst the Pagan authors. The highest number of citations is in the Stromata, followed by Protrepticus and the Paedagogus - and

6 The laws were enacted in 202, under the governor Laetus, and in 206, under Subatianus Aquila, during the reign of Septimius Severus.

7 Eus. Hist. eccl. 6,2,2. On these events, see Le Boulluec 2006, 44.

8 The cultural koine of this "Greco-Roman” Empire, to quote Veyne 2005, was shared by most of the Greek and Roman authors who had received the same training and paideia. On this point, see Pouderon and Doré 1998; Eshleman 2012, 199-202; and Van Hoof and Van Nuffelen 2015.

9 On the historical situation in Egypt, and particularly in Alexandria, see Bowersock 1996; Haas 1997; Harris and Ruffini 2004; and Arcari 2016. See also Martin 1996, 117-201 and Le Boulluec 2006, 29-60.

10 I shall use the terms "Pagans" and "Christians" only to separate the worshippers of traditional religions and the followers of Jesus. On the problematic use of these terms as religious categories, see Chuvin 2011, 15-20, North 2005 and Cameron 2011, 14-32.

11 On the cohabitation of Christians, Gnostics, and Jews in the Alexandria of the $2^{\text {nd }} c . A D$, see Arcari 2016 and more precisely Pouderon 2016.

12 See Chadwick 1966 and Le Boulluec 2006.

13 Stählin 1936, 1-66, provides a useful index of the more than three hundreds quotations featuring in the works of Clement. For an analysis of some specific cases, see des Places 1986, 1988, 1990a and 1990b. More generally, on the role of Euripides in Christian apologetic works, see Zeegers-Vander Vorst 1972, 36-38. 
not surprisingly so, considering that the Stromata are presented as an anthology. ${ }^{14}$ Clement cites thirty-one plays in total, twelve of which are still known today in their totality. ${ }^{15}$ As André Tuillier has noted, the plays cited by Clement include "the most popular tragedies of all periods, in the Orient and the Occident: Medea, Orestes, the Phoenician Women and the Bacchae."16 Tuillier also remarks that, except from three, all the plays cited by Clement are also presented by Plutarch. In contrast, Clement has only ten plays in common with the Deipnosophistae of Athenaeus of Naucratis: Antigone, Antiope, Auge, Bacchae, Medea, Oeneus, Orestes, (Pirithous), Telephus and the Phoenician Women. ${ }^{17}$ As Annewies Van Den Hoek suggested, "[s] ome borrowings certainly came in a more direct way, namely through first-hand acquaintance with individual authors. Some may initially have come through memory."18

\section{Reading Euripides}

In order to understand the importance of Clement of Alexandria in the Euripides tradition, a preliminary consideration is in order. Before the end of the $4^{\text {th }} \mathrm{c}$. AD, there was no real difference in scholarly training and induction between the Pagans and the Christians. ${ }^{19}$ The canonical literary and rhetorical texts continued to be the same. These texts established the standards of the Greek-Roman paideia and underlined what Peter Brown referred to as a koine of the religious and social experience. ${ }^{20}$ The Euripidean verses lend themselves to different functions and objectives in the works of Clement. Below I try to classify these uses.

14 In Stromata, Clement quotes twenty Euripidean plays: Aegeus, Alexander, Antigone, Antiope, Auge, Bacchae, Erechtheus, Cresphontes, Medea, Oeneus, Oenomaus, Orestes, (Pirithous), Protesilaus, Telephus, Temenides, Hypsipyle, Phoenician Women, Phoenix, Chrysippus. In the Protrepticus, he cites seven known plays - Alcestis, Bacchae, Ion, Iphigenia in Tauris, Orestes, Phoenician Women, Trojan Women - plus several fragments. In the Paedagogus, he cites five known plays - Bacchae, Hecuba, Hippolytus, Iphigenia in Aulis, Orestes - plus two fragments.

15 Van Den Hoek 1996, 231.

16 Tuillier 1968, 86 (translation of the author).

17 Tuillier 1968, 87.

18 Van Den Hoek 1996, 224.

19 On the absence of “Christian schools" in Roman Empire, see Marrou 1958, 416. For a bibliographical analysis, see Lugaresi 2004. Pouderon 1998 suggests that during the $2^{\text {nd }} \mathrm{c}$. AD, some places of the Empire - particularly Alexandria, Rome and Athens - had become "intellectual centres" of a Christian teaching tradition.

20 According to Brown 1978, 97, this koine unified the peoples of the cities of the ancient Mediterranean Sea. 


\subsection{Gnomic Value}

The first, and most neutral, function of Euripidean verses has to do with their gnomic value. This use follows in the footsteps of a many-century-long tradition. In the third book of the Paedagogus, for instance, Clement expounds on couple's life. Talking about chastity, the author cites three verses from the Orestes:

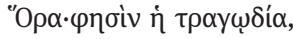

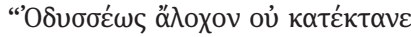

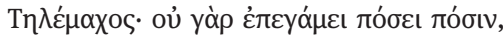

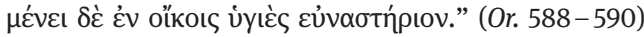

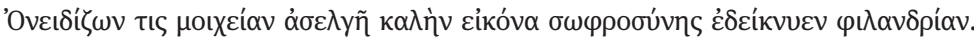

See, says the tragedy,

"The consort of Ulysses was not killed

by Telemachus; for she did not take a husband in addition to a husband,

but in the house the marriage-bed remains unpolluted." (Or. 588-590)

Reproaching foul adultery, he showed the fair image of chastity in affection to her husband.

(Paed. 3,41,4, tr. Wilson)

The plot of the play is not important here. The verses serve rather as evidence of the wisdom contained in the behaviour advocated by Clement.

\subsection{Antipagan Polemic}

Secondly, Euripides' verses can enter into Clement's anti-pagan polemic. In this case, citing a verse serves to point to a Pagan belief or practice that is worth of condemnation. An apt illustration is in the Paedagogus, where Clement bashes the use of crowns by citing two verses from the Hippolytus:

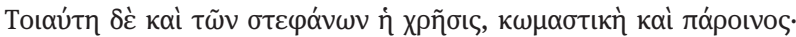

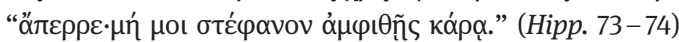

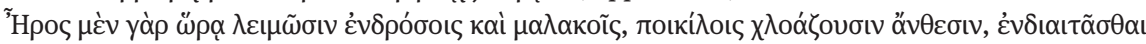

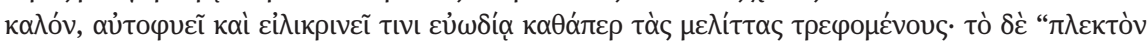

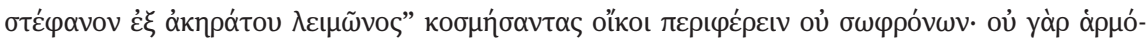

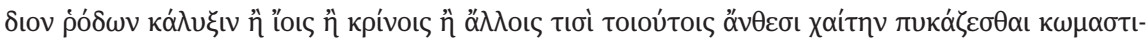

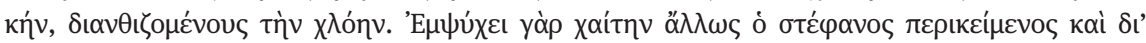

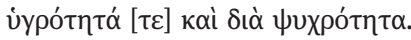

Such a use of crowns, also, has degenerated to scenes of revelry and intoxication. "Do not encircle my head with a crown" (Hipp. 73-74), for in the springtime it is delightful to while away the time on the dewy meads, while soft and many-coloured flowers are in bloom, and, like the bees, enjoy a natural and pure fragrance. But to adorn one's self with "a crown woven from the fresh mead," and wear it at home, were unfit for a man of temperance. For it is not suitable to fill the wanton hair with rose-leaves, or violets, or lilies, or other such flowers, stripping the sward of its flowers. For a crown encircling the head cools the hair, both on account of its moisture and its coolness. (Paed. 2,70,2, tr. Wilson) 
The source of the first verse is unknown, but the other two verses are from Euripides' Hippolytus. Both examples serve to stress the contrast between the life of Pagans and that of Christians. Christians, so the plea goes, shall avoid all Pagan practices not only for the sake of their soul's salvation, but also for their physical health and wellbeing.

Elsewhere, the anti-pagan polemic targets at ancient authors and blames them of plagiarism and theft from the Scriptures. In the sixth book of the Stromata, Clement offers a long list of citations that would illustrate this plagiarism. Commenting about wealth in a fragment of Chrysippus: ${ }^{21}$

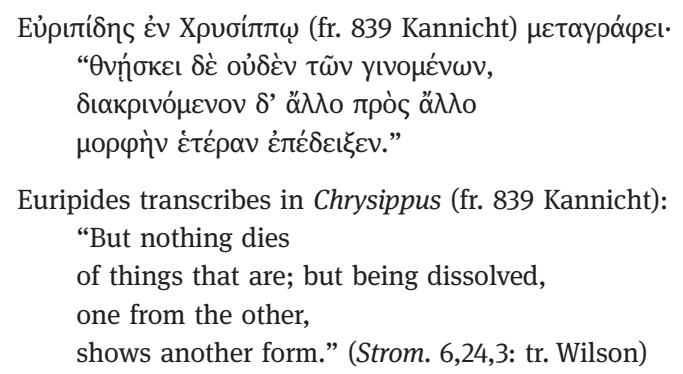

Here too the context of the scene is of little relevance. The goal is to show the unmatched superiority of the Christian creed over the pagan one.

\subsection{Euripides as Witness of Christian Truth}

The third way in which Clement uses quotations from Euripides is as evidence that certain Pagans already knew the Christian truth. ${ }^{22}$ In the sixth chapter of his Protrepticus, after a long critique of Greek philosophers and their mistakes, Clement tries to show that Greek thought was not completely alien to Christian revelation. For instance, Clement concedes that Plato was rights about the nature of God:

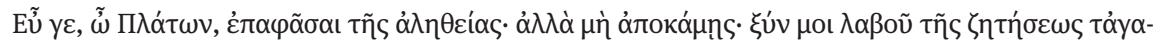

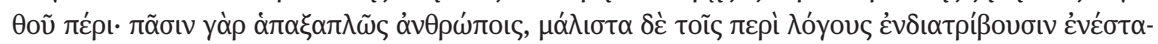

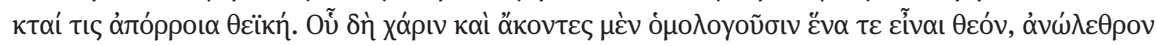

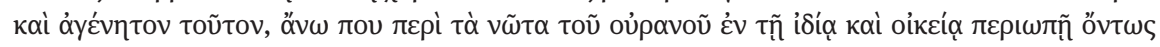

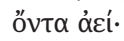

Well done, Plato! Thou hast touched on the truth. But do not flag. Undertake with me the inquiry respecting the Good. For into all men whatever, especially those who are occupied with intellectual pursuits, a certain divine effluence has been instilled; wherefore, though reluctantly, they

21 For a commentary on fr. 839, see Jouan and Van Looy 2002, 386-387.

22 On this rhetorical strategy in Christian works see, Ridings 1995 and Herrero 2010, 224-238. On the Platonic influence on Clement's works, see Lilla 1971, 41-45; Le Boulluec 2006, 63-79; and Riedweg $1987,117-161$. 
confess that God is one, indestructible, unbegotten, and that somewhere above in the tracts of heaven, in His own peculiar appropriate eminence, whence He surveys all things, He has an existence true and eternal. (Protr. 6,68,2, tr. Butterworth)

In order to confirm that, he cites a fragment that he attributes explicitly to Euripides (fr. 1129 Nauck = TrGF 2, adesp. fr. 622 Kannicht-Snell):

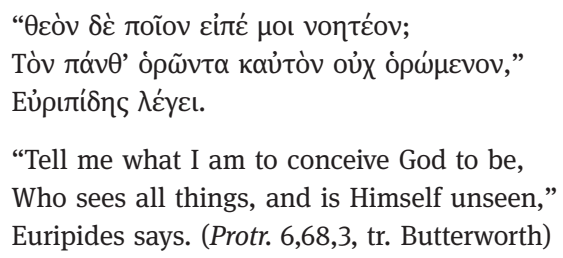

The same fragment features in another Christian text, but it is probably inauthentic. ${ }^{23}$ What matters here is that Clement is using the auctoritas of Euripides to confirm his opinion about Plato.

\section{Rewriting Euripides' Bacchae}

Aside from these specific uses, quotations from Euripides pervade the rhetoric of Clement and become a crucial component of his discourse. In what follows, I shall focus on this widespread mode of citation, which brings into full light the significance of Euripides in Clement's work.

The most interesting example of this rewriting concerns the Bacchae. This text is not only of literary interest to Christian authors. It also offered them the chance to deal with the Dionysian matter, by bringing selected words and images into new Christian context. In the eyes of certain Christian authors, the Bacchae tragedy plays then almost as a reference text to the new cult. ${ }^{24}$ The intrigue of Euripides' last tragedy allowed a series of analogies between the history of Dionysus and that of Christ. The arrival of the Greek god at Thebes in the form of a man; the opposition of the political power towards its new cult; the imprisonment as well as the interrogation of Dionysus - all these themes lend themselves to suggestive parallels with the vicissitudes recounted in the Christians' Scriptures. ${ }^{25}$

Against this backdrop, a crucial point to highlight is that Clement uses the Bacchae differently depending on the context. The citations serve therefore to a panoply of objectives in Clement's works.

23 Ps.-Justin, De monarchia 2. On the inauthenticity of the fragment, see Kannicht 1981, 172. See also Zeegers-Vander Vorst 1972, 208 and Riedweg 1994, 355.

24 Among the many publications on this question, see the recent works of Herrero 2010; Jourdan 2010, 195-220; Massa 2014, 167-188; and Friesen 2015, 120-133.

25 On these parallels, see also Seaford 1997 and Seaford 2006, 122-129. 


\subsection{Pentheus and Tiresias as New Christian Characters}

Let us begin with the Protrepticus. In the last chapter of this work, after a long digression against the Pagan religion, and in particular against mystery cults, Clement advocates for following the message of Christ and for abandoning the traditions of the Greeks. ${ }^{26}$ Rich in allegorical images and sophisticated in style, this last chapter is the climax of the entire work. And it is precisely at this point of high rhetorical tension that Clement evokes Dionysus and the imaginary of the Bacchae. ${ }^{27}$

Clement keeps the Bacchae in store for this last chapter. The second chapter of Protrepticus offers instead one of the richest reflection on the image of Dionysus by a

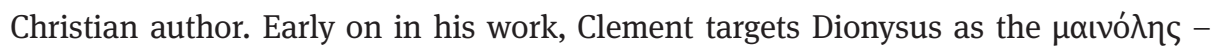
which means both "mad" and "he who renders others mad". ${ }^{28}$ Here we see at play a strategy shared by Christian authors: redirecting the madness of his enemies to the god himself. Clement connects this representation to the celebrations where

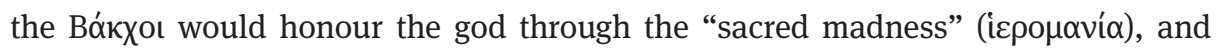
the rite of omophagia. ${ }^{29}$ Dionysus and his followers appear here as sharing the same emotional state. This serves in the Christian polemic to deny the divinity of false gods. The state of madness of the god is tied to his drunkenness. Also Theophilus of Antioch, representing the Greek gods as dead men and mentioning the pagans' recounts about the horrors of their gods, cites Dionysus as he "who is drunk" ( $\mu \varepsilon$ $\theta v \dot{\omega} \omega v)$ and "who is mad" ( $\mu \alpha$ เvó $\mu \varepsilon v o \varsigma) .{ }^{30}$ Here we see at play another accusation typical of the Christians: the wine of Dionysus drives one to madness, while Christ taught men the value of moderation.

The citations of Bacchae in the second chapter do not serve to attack the mysteries of Dionysus, but rather to create a new Christian imagery. One of the most interesting examples of the operation realized on Euripides' Bacchae are the exhortations addressed towards Pentheus and Tiresias. Clement addresses directly the two characters of the tragedy, inviting them to abandon their previous life. This move follows the intrigue of the Bacchae, where Dionysus' epiphany had obliged the inhabitants of Thebes to choose between accepting back the cult of Dionysus or refusing it. The passage on Pentheus reads as follows:

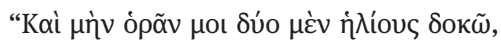

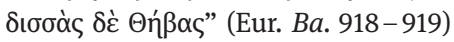

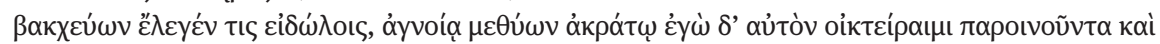

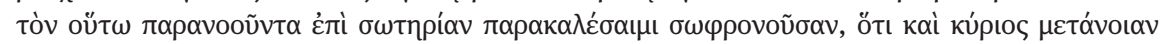

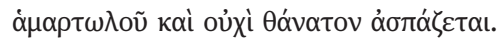

26 On Clement's rhetorical strategy in the last chapter of the Protrepticus, see Stenecker 1967, 165 170 and Zeegers-Vander Vorst 1972, 278- 285.

27 For a general interpretation of the Bacchae, see Beltrametti 2007 with bibliography.

28 See, for example, Corn. Nat. deor. 60,8.

29 See Clem. Al. Protr. 2,12,2.

30 Theophil. Autol. 1,9. 


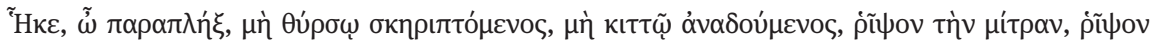

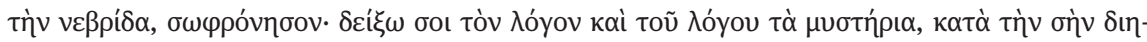

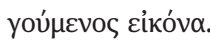

"And in truth! Methinks I see a pair of suns

And a double Thebes" (Eur. Ba. 918-919)

said one who was revelling in frenzy through idols, drunk with sheer ignorance. I would pity him in his drunkenness, and would appeal to him to return from this madness to sober salvation, seeing that the Lord also welcomes the repentance, and not the death, of a sinner.

Come, thou frenzy-stricken one, not resting on thy wand, not wreathed with ivy! Cast off thy headdress; cast off the fawnskin; return to soberness! I shall show you the Word, and the Word's mysteries, describing them according to thine own semblance of them.

(Protr. 12,118,5-119,1, tr. Butterworth)

Albeit not explicit, the reference to Pentheus is clear due to the citation of two tragic verses pronounced by the sovereign of Thebes in the beginning of the fourth episode of the tragedy. ${ }^{31}$ Clement outright emphasizes his compassion for this drunken individual and highlights that the Christians' god appreciates the metanoia ("conversion") of the sinner, and not his death. ${ }^{32}$ Here the author is clearly constructing a contrast between Christ and Dionysus, who, at the end of the Euripidean tragedy, appears distant and inaccessible after having driven Agave to butcher Pentheus, her son, in accordance with the Dionysian ritual. Wrapped in his anger, Dionysus is insensitive to supplications and suffering. His punishment descends over the city of Thebes and destroys the genos of Cadmus, as promised at the beginning of the tragedy. ${ }^{33}$ In Clement, Pentheus, the punished culprit and sacrificed by the will of Dionysus, becomes one more sinner who can still aspire to salvation. The quotation of Bacchae serves therefore to invite Pentheus to conversion.

Thereafter, Clement moves his attention on Tiresias. Here again the author makes a specific reference to the Bacchae, rather than more generally to the mythical tales featuring Tiresias. In the Bacchae, Tiresias decided to sustain the cult of the new god and, despite his old age, to take part in the Bacchic rituals celebrated on mount Cithaeron. ${ }^{34}$ And it is precisely as supporter of the new cult that Clement addresses Tiresias:

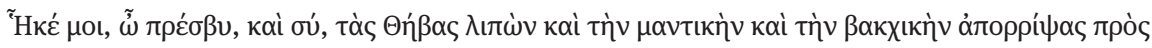

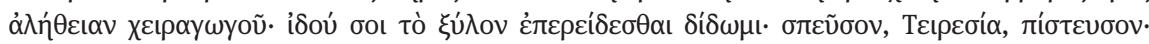

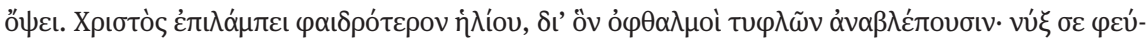

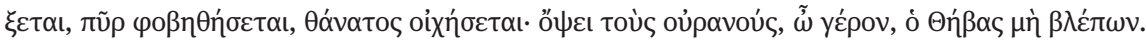

31 On Pentheus diplopia, see Dodds 1960, 193; Seaford 1987; and Goldhill 1988.

32 On the Christian category of "conversion", see Charles-Saget 1998; Perrin 2007; and Bøgh 2014. On the difference between Dionysiac membership and Christian conversion, see Massa 2011.

33 Eur. $B a .1345$ (Dionysus): "You were late in understanding us. When you should have, you did not

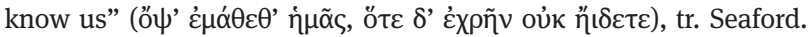

34 Eur. Ba. $174-177$. 
Come to me, old man, come you too! Quit Thebes; fling away thy prophecy and Bacchic revelry and be led by the hand to truth. Behold, I give you the wood to lean upon. Haste, Teiresias, believe! You shalt have sight. Christ, by whom the eyes of the blind see again, shine upon you more brightly than the sun. Night shall flee from you; fire shall fear you; death shall depart from you. You shalt see heaven, old man, though you cannot see Thebes. (Protr. 12,119,3, tr. Butterworth)

In his plea for conversation, Clement recalls two aspects specific to the Tiresias of Euripides: the abandonment of Thebes, the city of the Bacchae, and the mantic art of Bacchic rituals.

Clement nonetheless proposes to lead Tiresias and Cadmus, whom Euripides portrays as a supporter of Tiresias, ${ }^{35}$ into the truth of God. Clement is rewriting an episode of the Bacchae. Both in the play and the treatise, the blindness of Tiresias may hamper his divine election. The themes of light and sight feature prominently in Clement's theological thought. The couples youth/old age and sight/blindness stand for the contraposition between the Pagan system, dedicated to the cult of fake gods, and the renaissance through the convention to Christianity. In the Paedagogus, indeed, Clement uses the metaphor of blindness to describe the stage previous to that of baptism. The terms of light and of illumination (photisma) are at the heart of the Christian vocabulary for ancient baptism. The promise that Tiresias will regain sight - "You shalt see heaven, old man, though you cannot see Thebes" - refers to illumination, which is part of the baptismal conception of the Great Church.

This last passage concerning Tiresias contains another element worth noting. In the Bacchae, Tiresias was holding a thyrsus, while in the Protrepticus Clement offers him wood so that he can lean on it. In the Christian language, however, xylon indicates the wood of the cross. "To lean upon the wood" means to lean on the cross, and thus to rely on Christ. The Christian cross substituted the Dionysiac thyrsus.

The use of the Bacchae of Euripides is far from incidental. It rather reflects the intent to interpret the language and the characters of the tragedy according to the new Christian coordinates. As Clement himself put it in the last chapter of his Protrepticus, "I will show thee the Word, and the Word's mysteries, describing them ac-

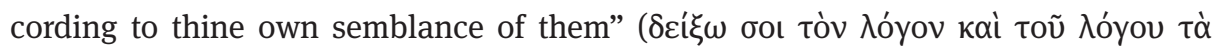

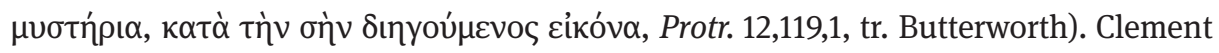
is well aware that the new Christian message cannot be accepted without a process of translation into the categories of the Greek culture. And Clement, as Guy Stroumsa has noted, "prefers to transform rather than reject." 36

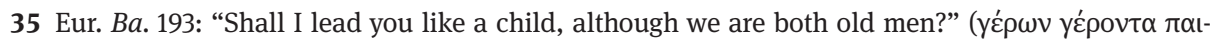

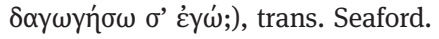

36 Stroumsa 2004, 308. 


\subsection{Dionysiac and Christian Initiations}

Another example of the rewriting of the Bacchae of Euripides is in the Stromata. This is the last work of Clement, which he composed after having left Alexandria. In discussing about Gnostic perfection, the author claims the existence of secret teachings and doctrines, which can only be transmitted to those who have accomplished their specific path of initiation. ${ }^{37}$ Although Clement is here speaking of a Christian initiation he uses - and here is the interesting point - the words of the Euripidean Dionysus in interrogation of the second episode of the drama:

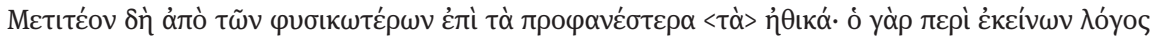

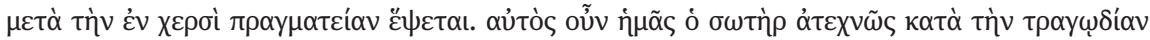
$\mu \nu \sigma \tau \alpha \gamma \omega \gamma \varepsilon \tilde{\imath}$,

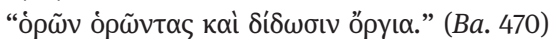

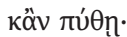

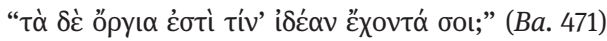

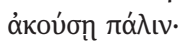

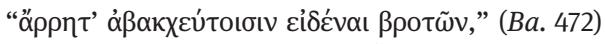

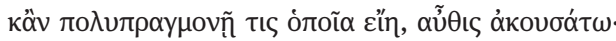

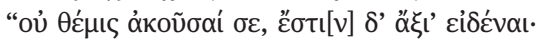

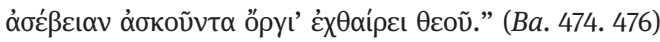

But we must pass from physics to ethics, which are clearer; for the discourse concerning these will follow after the treatise in hand. The Saviour Himself, then, plainly initiates us into the mysteries, according to the words of the tragedy:

"Seeing those who see, he also gives the orgies." $(\mathrm{Ba} .470)$

And if you ask,

"These orgies, what is their nature?" (Ba. 471)

You will hear again:

"It is forbidden to mortals uninitiated in the Bacchic rites to know." (Ba. 472)

And if any one will inquire curiously what they are, let him hear:

"It is not lawful for you to hear, but they are worth knowing;

The rites of the God detesthim who practices impiety." (Ba. 474. 476)

(Strom. 4,162,2-4, tr. Wilson)

Christ uses the words of Dionysus. ${ }^{38}$ Here I wish to draw attention to a minor change of form that Clement makes to the original text. In the entire manuscript tradition, the accusative ó $\rho \tilde{\omega} \nu \tau \alpha$ of the Euripidean text is the plural - ó $\tilde{\omega} \nu \tau \alpha \varsigma$. This slight variation allows Clement to make of the discussion between Pentheus and Dionysus in Bacchae a dialogue between Christ and the Apostles. The verses about the famous

37 On the interpretation of gnosis in the Stromata, see Osborn 2005, 255-257.

38 In the Bacchae, the moment of actually seeing Dionysus is a fundamental component of initiation. As Vernant 1986, 249 has noted, the reciprocity of the look is necessary, "quand, par la grâce de Dionysos, s'est instituée, comme un jeu de miroirs, une entière réversibilité entre le fidèle voyant et le dieu visible, chacun étant à la fois et en même temps, par rapport à l'autre, celui qui voit, celui qui fait voir." 
rituals at the mount Cithaeron by the followers of Dionysus play as if they described in fact a Christian representation. What Euripides sets into scene becomes the instrument that allows for the understanding of the value of the mission of Christ and his disciples. The Bacchae seems therefore to play for Clement the role of the key text on dionysism with which he can fruitfully engage for his purposes.

\subsection{Pentheus as the "Old Man"}

The Bacchae found their way also in the Paedagogus, a work that collects a series of precepts and rules for abiding to the Christian teachings. In line with the function of this work, the function of citation is different than in the previous examples. In the second book, Clement analyzes the problems related to the consummation of wine by Christians. While he describes the physical effects of excessive drinking, he cites a Euripidean verse:

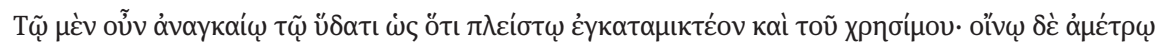

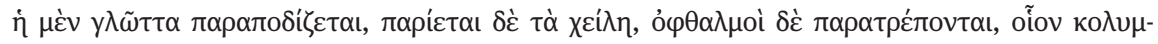

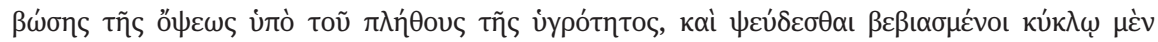

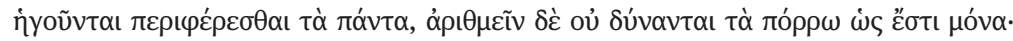

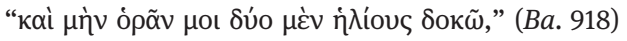

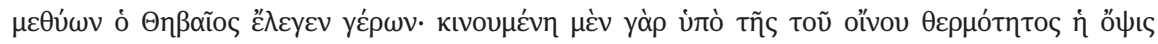

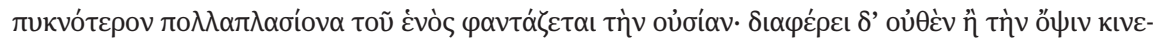

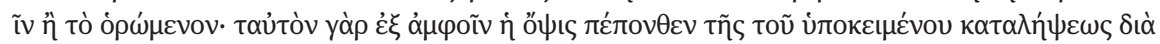

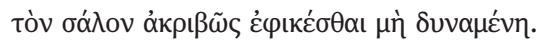

By an immoderate quantity of wine the tongue is impeded; the lips are relaxed; the eyes roll wildly, the sight, as it were, swimming through the quantity of moisture; and compelled to deceive, they think that everything is revolving round them, and cannot count distant objects as single.

"And, in truth, methinks I see two suns," (Ba. 918)

said the Theban old man in his cups. For the sight, being disturbed by the heat of the wine, frequently fancies the substance of one object to be manifold. And there is no difference between moving the eye or the object seen. For both have the same effect on the sight, which, on account of the fluctuation, cannot accurately obtain a perception of the object. (Paed. 2,24,2, tr. Wilson)

In the original scene, it is Pentheus who, on his way out of the palace disguised as a maenad, describes the altered perceptions due to wine consumption. Clement puts this verse in the mouth of an old man. This change is very unlikely a mistake, considering that Clement had already correctly cited the same verse in the Protrepticus.

This citation, I suggest, shall be read and interpreted in light of the specific context of the text where it finds place. The Protrepticus was addressed primarily to a learned audience. Clement felt therefore bound to stick precisely to the cited sources. The broader readership of the Paedagogus, by contrast, allows Clement more leeway in his citations. It seems to me that Clement is trying to project onto the "old drunken Theban" the image of the "old man" of the biblical scriptures, the one who was not 
yet Christian, as he still belonged to the Pagan world. It is, in a way, as if Clement was saying that all Pagans are "old" men who have lived vicious lives, marked by the immoderate consumption of wine. In this perspective, we could imagine that Clement attributes this verse to Tiresias, the divine, the one who represented the religious power in the Euripidean play. In this vein, it is also important to recall that Clement wanted to link the bad consumption of wine to the devotees of the god of wine, Dionysus, in a trend that placed the Greek god in opposition to Christ. ${ }^{39}$

\section{Conclusions}

The role of religion within the Roman Empire led to the emergence of a new discourse on religion. The early and powerful influence of Christian authors built a new rhetoric, with a strong accent on distinguishing the true/unique religion (or the orthodoxy) from superstition, heresy, or false belief; in other words, from the "religions of Others" (or the heterodoxy). In order to do this, Christian authors relentlessly compared, classified, typologised, assigned spatial and temporal coordinates, and hierarchized. They did so with respect to other religions and within the horizon of various forms of Christianity.

The picture that I offered above shows the importance of Euripides' plays in the culture and literary construction of Clement of Alexandria. It also shows that Christians faced real-world-type of challenges. Hence condemning Dionysiac cults serves Clement not only to mark the difference between Paganism and Christianity, but also to trace the frontiers of the Christian identity through the quotations of Euripides.

The followers of Jesus underwent major processes of transcodification, exchange and assimilation under the Roman Empire. The alienation, the rejection and the stigmatisation of uses and behaviours, have been some of the most significant dynamics in the construction of the "Christian religion". Euripides, as I have tried to show, played a role in this process of cultural transfers.

\section{Bibliography:}

Arcari 2016: Luca Arcari (ed.), Beyond Conflicts. Cultural and Religious Cohabitations in Alexandria and Egypt between the $1^{\text {st }}$ and the $6^{\text {th }}$ Century CE, Tübingen.

Beltrametti 2007: Anna Beltrametti, "La visita del giovane dio. Dalla drammaturgia di Dürrenmatt alla politica di Archelao", in Anna Beltrametti (ed.), Studi e materiali per le Baccanti di Euripide. Storia, Memorie, Spettacoli, Pavia, 13-64.

Bøgh 2014: Birgitte S. Bøgh (ed.), Conversion and initiation in Antiquity: Shifting Identities, Creating Change, Frankfurt/York.

39 On the opposition between Dionysiac and Christian wine, see Massa 2014, 203-249, with bibliography. 
Bowersock 1996: Glen W. Bowersock, "Late Antique Alexandria", in: John J. Walsh and T. F. Reese (edd.), Alexandria and Alexandrianism, Malibu, Ca., 263-272.

Brown 1978: Peter Brown, The Making of Late Antiquity, London/Cambridge, Mass.

Cameron 2011: Alan Cameron, The Last Pagans of Rome, Oxford.

Chadwick 1966: Henry Chadwick, Early Christian Thought and the Classical Tradition: Studies in Justin, Clement and Origen, Oxford.

Charles-Saget 1998: Annick Charles-Saget, "Sur quelques formes originaires de la constitution de soi”, in: Annick Charles-Saget (ed.), Retour, repentir et constitution de soi, Paris, 13-36.

Chuvin ${ }^{2} 2011$ : Pierre Chuvin, Chronique des derniers païens. La disparition du paganisme dans l'Empire romain, Paris.

des Places 1986: Édouard des Places, "Les citations profanes de Clément d'Alexandrie dans le III Stromate", Revue des Études Grecques 99, 54-62.

des Places 1988: Édouard des Places, "Les citations profanes du IV Stromate de Clémente d'Alexandrie", Revue des Études Anciennes 90, 389-397.

des Places 1990a: Édouard des Places, "Les citations profanes de Clément d’Alexandrie dans le $\mathrm{Vl}^{\mathrm{e}}$ Stromate", Revue des Études Anciennes 92, 109-119.

des Places 1990b: Édouard des Places, "Les citations profanes de Clément d’Alexandrie dans le VII Stromate”, Revue des Études Anciennes 92, 297-303.

Dodds ${ }^{2} 1960$ : Eric Robert Dodds, Euripides, Bacchae, edited with introduction and commentary, Oxford.

Eshleman 2012: Kendra Eshleman, The Social World of Intellectuals in the Roman Empire: Sophists, Philosophers, and Christians. Greek Culture in the Roman World, Cambridge/New York.

Friesen 2015: Courtney Friesen, Reading Dionysus: Euripides' Bacchae and the Cultural Contestations of Greeks, Jews, Romans, and Christians, Tübingen.

Goldhill 1988: Simon Goldhill, "Doubling and Recognition in the Bacchae”, Mettis 3, 137-155.

Haas 1997: Christopher Haas, Alexandria in Late Antiquity. Topography and Social Conflict, Baltimore-London.

Harris, Ruffini 2004: William V. Harris and Giovanni Ruffini (edd.), Ancient Alexandria Between Egypt and Greece, Leiden/Boston.

Herrero 2010: Miguel Herrero, Orphism and Christianity in Late Antiquity, Berlin/New York (Spanish edition, Madrid 2007).

Jourdan 2010: Fabienne Jourdan, Orphée et les chrétiens: la réception du mythe d'Orphée dans la littérature chrétienne grecque des cinq premiers siècles, vol. 1, Paris.

Junod 1980: Éric Junod, “Un écho d'une controverse autour de la pénitence: l'histoire de l'Apôtre Jean et du chef des Brigands chez Clément d'Alexandrie (Quis dives salvetur 42,1-15) ", Revue d'Histoire et de Philosophie Religieuses 60, 153-160.

Kannicht 1981: Tragicorum Graecorum Fragmenta (TrGF), vol. 2: Fragmenta adespota; testimonia volumini 1 addenda; indices ad volumina 1 et 2, edd. Richard Kannicht et Bruno Snell, Göttingen.

Le Boulluec 2006: Alain Le Boulluec, Alexandrie antique et chrétienne: Clément et Origène, Paris.

Lilla 1971: Salvatore R. C. Lilla, Clement of Alexandria: A Study in Christian Platonism and Gnosticism, Oxford.

Lugaresi 2004: Leonardo Lugaresi, "Studenti cristiani e scuola pagana. Didaskaloi, logoi e philia dal Discorso di ringraziamento a Origene all'Orazione funebre per Basilio di Gregorio Nazianzeno", Cristianesimo nella storia 25, 779-832.

MacMullen 1981: Ramsay MacMullen, Paganism in the Roman Empire, New Haven/London.

Marrou 1958: Henri Marrou, Histoire de l'éducation dans l'antiquité, Paris.

Martin 1996: Annick Martin, Athanase d'Alexandrie et l'église d'Égypte au IVe siècle (328-373), Roma. 
Massa 2011: Francesco Massa, "Tra adesione dionisiaca e conversione cristiana: Clemente di Alessandria e il Tiresia delle Baccanti di Euripide”, Quaderni Urbinati di Cultura Classica 97, $147-166$.

Massa 2014: Francesco Massa, Tra la vigna e la croce. Dioniso nei discorsi letterari e figurativi christiani (II-IV secolo), Stuttgart.

Massa 2016: Francesco Massa, "La notion de 'mystères' au II siècle de notre ère: regards païens et Christian turn", in: Nicole Belayche and Francesco Massa (edd.), Les "cultes à mystères": retour sur une catégorie, Mètis NS 14, 109-132.

Massa forthcoming: Francesco Massa, "Les mystères chez Eusèbe de Césarée: entre débat philosophique et polémique religieuse”, in: Philippe Hoffmann, Alain Le Boulluec, Luciana G. Soares, and Andrei Timotin (edd.), Exégèse, révélation et formation des dogmes dans l'Antiquité tardive, Paris.

North 2005: John North, "Pagans, Polytheists and the Pendulum", in: William V. Harris (ed.), The Spread of Christianity in the First Four Centuries. Essays in Explanation, Leiden/Boston, $125-143$.

Osborn 2005: Eric F. Osborn, Clement of Alexandria, Cambridge.

Perrin 2007: Michel-Yves Perrin, "De quelques homologies entre ralliements confessionnels en régime chrétien et adhésion au christianisme dans l'Antiquité tardive", Mediterranea 4, $263-280$.

Pouderon 1998: Bernard Pouderon, "Réflexions sur la formation d'une élite intellectuelle chrétienne au II e siècle: les " écoles " d'Athènes, de Rome et d'Alexandrie", in: Pouderon and Doré 2016, 237-269.

Pouderon 2016: Bernard Pouderon, “'Jewish,' 'Christian' and 'Gnostic' Groups in Alexandria during the $2^{\text {nd }}$ Cent.: Between Approval and Expulsion”, in: Arcari 2016, 155-176.

Pouderon and Doré 1998: Bernard Pouderon and Joseph Doré (edd.), Les apologistes chrétiens et la culture grecque, Paris.

Ridings 1995: Daniel Ridings, The Attic Moses. The Dependency Theme in Some Early Christian Writers, Goteborg.

Riedweg 1994: Christoph Riedweg, Ps.-Justin (Markellos von Ancyra?), Ad Graecos de vera religione (bisher Cohortatio ad Graecos): Einleitung und Kommentar, Basel.

Riedweg 1987: Christoph Riedweg, Mysterienterminologie bei Platon, Philon und Klemens von Alexandrien, Berlin/New York.

Seaford 1987: Richard Seaford, “Pentheus’ Vision: Bacchae 918-922”, Classical Quarterly 37, $76-78$.

Seaford 1997: Richard Seaford, "Lightening and Earthquake in the Bacchae and the Acts of the Apostles", in: Alan B. Lloyd (ed.), What is a God? Studies in the Nature of Greek Divinity, London, 139-151.

Seaford 2006: Richard Seaford, Dionysos, London/New York.

Stählin 1936: Clemens Alexandrinus, Bd. IV: Register, hg.v. Otto Stählin, Leipzig.

Steneker 1967: Henricus Steneker, Peithous demiourgia: observations sur la fonction du style dans le Protreptique de Clément d'Alexandrie, Nijmegen.

Stroumsa 2004: Guy G. Stroumsa, "Cultural Memory in Early Christianity: Clement of Alexandria and the History of Religions", in: Johan P. Arnason, Schmuel N. Eisenstadt, and Björn Wittrock (edd.), Axial Civilisation and World History, Jerusalem Studies in Religion and Culture 4, $295-317$.

Tuillier 1968: André Tuillier, Recherches critiques sur la tradition du texte d'Euripide, Paris.

Van Den Hoek 1996: Annewies Van Den Hoek, "Techniques of Quotation in Clement of Alexandria. A View of Ancient Literary Working Methods”, Vigiliae Christianae 50, 223-243. 
Van Hoof and Van Nuffelen 2015: Lieve Van Hoof and Peter Van Nuffelen (edd.), Literature and Society in the Fourth Century AD: Performing Paideia, Constructing the Present, Presenting the Self, Leiden/Boston.

Vernant 1986: Jean-Pierre Vernant, “Le Dionysos masqué des Bacchantes d’Euripide”, in: Jean-Pierre Vernant and Pierre Vidal-Naquet, Mythe et tragédie en Grèce ancienne. 2, Paris, $237-270$.

Veyne 2005: Paul Veyne, L'Empire gréco-romain, Paris.

Zeegers-Vander Vorst 1972: Nicole Zeegers-Vander Vorst, Les citations des poètes grecs chez les apologistes chrétiens du II siècle, Louvain. 
